\title{
Cellular migration as a Stress Relieving Strategy to Nanotoxicology
}

\author{
Ansie Martin* and Angshuman Sarkar \\ Department of Biological Sciences, KK Birla Goa Campus, India
}

Submission: December 08, 2017; Published: April 09, 2018

*Corresponding author: Ansie Martin, CMBL, Department of Biological Sciences, Birla Institute of Technology and Sciences, K K Birla Goa Campus, Sancoale, South Goa - 403726, India, Email: ansiemartin@gmail.com

\begin{abstract}
Nanoparticles are exponentially being used for their enormous sectors of applications. Human exposure and the ensuing distress is thus an inevitability. Despite the scores of ongoing research, there is still a lack of comprehensive revival strategies for treatment of the affected tissue. There is also no single standard procedure of prognosis, as the implications of toxicity are varied, and their symptoms also vary with each individual case of affliction. There is thus always a need for discovery of new targets and routes of treatment for better efficacy at therapy. We have discovered that encouraging cell migration could be one of these solutions.
\end{abstract}

Keywords : Nanoparticles; EMT; Stress; Recovery

Abbreviations : NP: Nano Particle; Me Ox: Metal Oxide; EMT: Epithelial to Mesenchymal Transition

\section{Introduction}

Nanotoxicology is a growing concern, particularly stress incited by exposure to Metal oxide (Me-Ox) nanoparticles (NPs), as they are commonly utilized in a broad range of fields [1]. Rising pollution and pulmonary distress are more apparent than ever before. There is thus a growing need for discovery and design of effective stress revival strategies to nanotoxicology.

From our research, we have discovered that encouraging cellular migration could be one such solution. Similar dose-time exposure to $\mathrm{TiO}_{2}$ NPs confers less lethality as compared to $\mathrm{ZnO}$ NP treatment with A549 cells. Remarkably, cellular migration is greatly enhanced with $\mathrm{TiO}_{2} \mathrm{NP}$ exposure against ZnO NPs (unpublished data) within the same dose-time bracket. This is the first documentation of its kind and has the potential to unravel novel routes of recovery strategies towards nanotoxicology.

\section{Cellular Migration}

Cellular migration broadly connotes to movement of cell from one location to another in two-dimensional space. Triggers for migration activate crucial cell surface receptors and induce morphological changes [2]. It is executed by a polarized cell morphology that enables protrusion over a trailing end. Potency for integrin associated attachment to basal lamina is also vital. Together the contraction and release of cytoskeletal structures enable cell movement [3].

Cell movement is ordained by a series of signal transduction pathways that include small GTPases, cytoskeleton-modifying proteins, kinases, lipid second messengers and motor proteins [4]. Cells achieve movement when different signaling cascades are consistently presented in specific locations within the cell while maintaining potency of response to extra cellular triggers [5]. Both epithelial and mesenchymal cells can migrate, although what external cues trigger specific cellular changes to channel directional movement is still under considerable research. However, mesenchymal phenotype has increased migratory and invasive capabilities, combined with a greater resistance to cell death [6]. Epithelial to mesenchymal transition (EMT) thus greatly enables migration and invasiveness, though migration alone does not necessitate EMT [7].

\section{Zone of Stress}

Every toxicological model presents a zone of stress, where in the cell survival is more sensitive than in other zones. For example, with in vitro models, cells close to the basal membrane may suffer from incumbent nutrient deprivation, lack of space and mechanical shear [8]. Further for adherent cultures, confluence influence dregression in proliferation has been extensively observed [9].

\section{Conclusion}

Thus, a greater potential for migration such as alteration in surrounding environment or by trans differential processes such as epithelial to mesenchymal transition may enable cells in moving away from this zone of stress, thereby enabling 
greater tolerance to stress and thus enhanced survival. Allows cells to float away from the lamina into a region more conducive for survival [10]. Any number of quorum sensing signals such as dissemination of chemokines and cytokines from the stress affected cells on the lamina may also affect the migrated cells to a lesser degree simply because of a lack of ample access.

This hypothesis is especially true with a monolayer tissue system, such as the internal lining of the pulmonary alveolus. Pulmonary tissue is highly susceptible to distress by aerosolized material in the atmosphere, that increasingly includes metal oxide nanoparticles.

\section{Declaration of Interest}

The Authors report no conflict of interest.

\section{Acknowledgements and Funding}

AS acknowledges support of a research grant from BRNS (DAE, Govt of India) (Grant No. 2011/37B/25/BRNS) for this work. Financial support to AM as fellowship from BRNS as well as from BITS Pilani is duly acknowledged.

\section{References}

1. Martin A, Sarkar A (2017) Overview on biological implications of metal oxide nanoparticle exposure to human alveolar A549 cell line. Nanotoxicology 11(6): 713-724.
2. De Fea, KA (2013) Arrestins in actin reorganization and cell migration. Prog Mol Biol Transl Sci 118: 205-222.

3. Petrie RJ, Doyle AD, Yamada KM (2009) Random versus directionally persistent cell migration. Nat Rev Mol Cell Biol 10(8): 538-549.

4. Charest PG, Firtel RA (2007) Big roles for small GTPases in the control of directed cell movement. Biochem J 401(2): 377-390.

5. Welf ES, Haugh JM (2012) Stochastic models of cell protrusion arising from spatiotemporal signaling and adhesion dynamics. Methods in cell biology 110: 223-241.

6. Kalluri R, Weinberg RA (2009) The basics of epithelial-mesenchymal transition. The Journal of clinical investigation 119(6): 1420.

7. Schaeffer D, Somarelli JA, Hanna G, Palmer GM, Garcia-Blanco MA, et al. (2014) Cellular migration and invasion uncoupled: increased migration is not an inexorable consequence of epithelial-to-mesenchymal transition. Mol Cell Biol 34(18): 3486-3499.

8. Zhang X, Huk DJ, Wang Q, Lincoln J, Zhao Y, et al. (2014) A microfluidic shear device that accommodates parallel high and low stress zones within the same culturing chamber. Biomicrofluidics 8(5): 054106.

9. McClain DA, Edelman GM (1980) Density-dependent stimulation and inhibition of cell growth by agents that disrupt microtubules. Proc Natl Acad Sci USA 77(5): 2748-2752.

10. Sarkar A, Parikh N, Hearn SA, Fuller MT, Tazuke SI, et al. (2007) Antagonistic roles of Rac and Rho in organizing the germ cell microenvironment. Curr Biol 17(14): 1253-1258.

\section{Your next submission with Juniper Publishers will reach you the below assets}

- Quality Editorial service

- Swift Peer Review

- Reprints availability

- E-prints Service

- Manuscript Podcast for convenient understanding

- Global attainment for your research

- Manuscript accessibility in different formats

( Pdf, E-pub, Full Text, Audio)

- Unceasing customer service

Track the below URL for one-step submission https://juniperpublishers.com/online-submission.php 